\title{
Eesti- ja Liivimaa libahundipärimus rahvapärase ontoloogia muutumise peegeldajana
}

\author{
Merili Metsvahi \\ Tartu Ülikooli kultuuriteaduste instituudi \\ eesti ja võrdleva rahvaluule osakonna kaasprofessor \\ merili.metsvahi@ut.ee
}

\begin{abstract}
Teesid: Artikkel käsitleb eesti libahundipärimust. 16. ja 17. sajandi nõiaprotsesside ajajärgul Eesti- ja Liivimaal levinud libahundiuskumusi võrreldakse nendega, mis leiduvad 19. ja 20. sajandi rahvajuttudes. Selgub, et need kaks ajalist pärimuskihti erinevad teineteisest rahvapärase maailmanägemise teisenemise tõttu vahepealsetel sajanditel. 16. ja 17. sajandil oli talupoegade seas valdav animistlik maailmanägemine, mille järgi inimene ja loom, hing ja keha ning organism ja tema keskkond olid teineteisega seotud tihedamalt ja teisel viisil kui nad on seda tänapäeva inimese maailmatunnetuses. 19. ja 20. sajandi pärimuses kajastuvad kategooriad on lähedased tänapäeva inimese dualistlikule maailmanägemisele.
\end{abstract}

Märksõnad: Eesti- ja Liivimaa, eesti rahvajutud, libahunt, neoanimism, nõiaprotsessid, rahvapärane maailmanägemine, rahvausund

\section{Sissejuhatus}

Käesolevas artiklis võrdlen omavahel kahest eri perioodist pärit libahundiuskumuste allikaid. Esimene periood hõlmab 16. ja 17. sajandit ning teine 19. ja 20. sajandit. Esimese perioodi alla kuulub nõiakohtuprotokollides leiduv informatsioon, aga kuna seda pole säilinud kuigi suurel hulgal, kaasan ka reisiraamatutes ja teistes tolle aja kirjalikes trükiallikates leiduva teabe Liivi- ja Eestimaa libahuntide kohta. Nii näiteks kirjutas Sebastian Münster oma maailmakirjelduse "Cosmographia" 1550. aastal ilmunud kordustrükis liivimaalaste võimest end hundiks muuta. Teise perioodi käsitlemisel piirdun Eesti Rahvaluule Arhiivis (ERA) leiduva libahundipärimusega, mõistes selle all nii libahuntide kohta käivaid usundilisi teateid, libahundimuistendeid kui ka -muinasjutte. Libahundimuinasjuttude üleskirjutamise aeg hõlmab umbes pooltteist sajandit alates 19. sajandi algusest ning libahundimuistendid ja usundilised teated on fikseeritud 19. sajandi lõpust 20. sajandi lõpuni. Et Eesti Rahvaluule Arhiivi käsikirjalisi tekste libahuntide kohta on kokku arvestatav 
hulk - peaaegu 1400 - ei ole ma selle perioodi allikate hulka kaasanud tolle perioodi trükiallikates leiduvat teavet libahuntide kohta.

Teine eristus, mille teen esimest ja teist ajajärku käsitledes, on geograafiline. Varasema perioodi puhul kasutan lisaks eestikeelse elanikkonna libahundipärimusele mõnevõrra ka lätikeelse elanikkonna pärimust alalt, mis jäi poliitiliselt samasse piirkonda - Liivimaale. Põhjenduseks on allikate nappus esimesest perioodist ning mitmed põnevad motiivid lätikeelse ala materjalis, aga ka asjaolu, et lätikeelse elanikkonna uskumusi kajastavad allikad on rikkalikumad, ent sisu poolest paljuski siiski võrreldavad eestlaste seast pärit ainestikuga. Teise perioodi puhul piirdun ainult ERA eestikeelse materjaliga, mida leidub rohkesti.

Lühikäsitluses pole võimalik keskenduda mõlemale: anda ammendav ülevaade ühte või teise perioodi kuuluvast materjalist ning mõtestada muutusi, mis nende kahe perioodi libahundipärimust võrreldes silma torkavad. Kuna materjali tutvustamisele olen pühendunud mõningates varasemates kirjutistes (Metsvahi 1999; Metsvahi 2019; Metsvahi 2011; Metsvahi 2001a; Metsvahi 2001b; Metsvahi 2000), annan eespool materjalist väga põgusa ja valikulise ülevaate ning sean seekordseks põhieesmärgiks hoopis muutuste mõtestamise. Selgitan, kuidas ja mis põhjustel muutus libahundipärimus eelmodernse aja vahetudes modernse vastu ${ }^{1}$.

Alustan mitte varasema, vaid hoopis hilisema perioodi libahundipärimuse tutvustamisest, refereerides selleks küll ainult ühte seni trükis avaldamata teksti, mis mõistagi ei ava kaugeltki kõiki libahundipärimuse nüansse. Seejärel liigun kõige varasema perioodi libahundipärimuse käsitlemise juurde. Kuna nähtuste, mõistete või kategooriate teke on nende mõistmises väga paljudes valdkondades võtmetähtsusega, tasub peatuda libahundipärimuse algusajal veidi põhjalikumalt. See annab ainest juurdlemaks, kuidas selline maailmamõistmise kategooria nagu libahunt välja sai kujuneda. Artikli teises pooles selgitan, millisel rahvapärasel ontoloogial põhineb libahundiusk ning kuidas ja millised muutused toimusid libahundi kujutelma mõtestamises aegade jooksul, kui vanapärane ja animistlik rahvapärane ontoloogia vahetus modernsema vastu.

\section{9. ja 20. sajandi libahundipärimus}

1888. aastal saatis Jaan Loskit Viljandimaalt Puhja kihelkonnast rahvaluule suurkogujale Jakob Hurdale loo sellest, kuidas Armi talu sulane Mats hundistus ja hiljem tagasi inimeseks muutus. Lühidalt oli lugu järgmine. Üsna külmal talvepäeval käisid Korvi küla mehed linnas vooris. Tagasiteel olid nad jõudnud 
umbes versta maad läbi suure metsa tulla, kui Mats nägi paremal pool teed männi all midagi kummalist. Ta läks maha ja nägi, et tegemist on hundinahaga. Mats mõtles, et on õnnega koos, sest saab selle pärast mõisahärrale maha müüa. Visanud naha üle õla, et seda ree peale panna, lippas ta voori tagasi. Ent seal selgus, et nahk on Matsi selja külge kinni jäänud. Mats muutus hundiks ning see hobune, kes tema ree ees oli, hakkas hunti märgates lõhkuma. Ka teised voorilised nägid nüüd hunti Matsi ree peal ning asusid teda hurjutama, hunt aga jäi paigale. Siis hakkasid voorilised hunti vemmaldega nüpeldama ning hunt põgenes metsa. Mõned imestasid, kuhu Mats jäänud on, ent kui üks nende seast ütles, et küllap sõi hunt Matsi ära, ei esitatud enam küsimusi. Voorilised viisid Matsi hobuse Armi peremehele ise ära. Kolme järgneva kuu jooksul käis üks hunt alailma küla kariloomi noolimas, ent koerad ajasid ta minema. Nädal enne jüripäeva, kui Armi talupere õhtusööki sööma asus, avanes järsku uks ning sisse astus võõras mees, kes kinnitas, et ta on nende sulane Mats. Tal oli kõht väga tühi ning ta tuli otsekohe sööma, kui pererahvas ta lauda kutsus. Matsi hääl oli muutunud jämedaks ja värisevaks ning nägu rikutud ja hirmus. Kui temalt aru päriti, kus ta kõik need kolm kuud on olnud, rääkis ta sellest, kuidas ta oli sunnitud hundiks muutuma ja hundi tegusid tegema. Talle oli suur nälg kallale tulnud ning ta oleks tahtnud mõne lambatalle, vasika või seapõrsa murda, aga koerad takistasid. Inimeseks tagasi sai ta nii, et kui ta ühte varssa kinni üritas püüda, jooksis see ümber kivi. Ümber kivi ringi joostes kukkus ta maha, mispeale kadus hundinahk ühtäkki ta seljast ära ning ta muutus tagasi inimeseks. (H I 2, 509/11 (1) < Puhja khk, Suure-Konguta - Jaan Loskit (1888).)

Kirjeldatud jutt ei ole tüüpiline libahundimuistend, vaid süžee poolest ainulaadne jutt ERAs. See on pikem ja mõnevõrra poeetilisem kui üks harilik libahundimuistend. Ometi leidub selles kirjanduslike lisandustega idiosünkraatilises jutustuses mitmeid eesti libahundimuistenditele tavalisi jooni ja motiive, nagu hundiks muutumine hundinaha abil (tavaliselt küll ei jää nahk ise selga kinni, vaid tõmmatakse ise meelega selga või siis visatakse teisele selga mõne pahatahtliku inimese poolt; vt nt Metsvahi 2011: 197-198, 200) ning inimesest hundiks muutumise viis kolm korda ümber kivi ringi käies (selle motiivi leviku sageduse kohta vt Metsvahi 1999: 119).

Kuigi enamik lugusid inimese hundiks muutumisest kolm ringi ümber kivi, puu või põõsa tehes kuulub ERAs meelelahutusmuistendite ${ }^{2}$ hulka, oli isegi veel 20. sajandi pärimuses mõnevõrra säilinud uskumus või pigem kahtlus, et kolm ringi ümber kivi käies võib inimesega midagi hirmuäratavat juhtuda - ta võib hundiks muutuda. 1963. aastal rääkis Anna Tali endisest Tori kihelkonnast rahvaluulekogujale Ellen Liivile, et kuigi ta hundiksmuutumise loitsu ei teadnud, ei julgenud ta kunagi kolm korda ümber oma kodu juures oleva suure kivi joosta, sest "viimati juhtubki midagi" (RKM II 156, 324/5, 84 < Tori 1963). 
Ka hundiks muutumine metsas ja hundiks muudetu tung otsekohe metsa joosta ning motiiv kellegi hundiks muudetu või vastu tahtmist hundiks saanu raskustest toidu kättesaamisel on 19. ja 20. sajandil Eestist üles tähendatud libahundimuistendites tavalised.

\section{Esimesed kirjalikud teated Liivimaa libahundiusu kohta}

Eesti rahvaluule kõige varasemasse kihistusse kuuluvad oletatavasti regilaulud. Tõsiasi, et regilauludes libahundi mõistet ega tegelaskuju ei esine, annab aimu sellest, et libahundi kujutelm ei saa olla väga vana. Ka keskaegsetes Eestija Liivimaa eluolu käsitlevates kroonikates ei mainita libahunti kordagi (Vähi 2011: 253). Väga põhjalikult Liivimaa libahundipärimust käsitlenud teadlase Hermann von Bruiningki järgi pole veel aastate 1546-1561 kohtumaterjalideski mitte ühtegi vihjet libahuntidele (Bruiningk 1924: 183).

Tegelikult on kohtuasju, milles süüalusele omistati hundiks muutumise võime, olnud juba ka 16. sajandi esimesel poolel, ent nende protokolle pole säilinud. Ajast veidi enne 1560. aastat on teada kahest Riias toimunud kohtuprotsessist, millel kõlas libahundiks käimise süüdistus (Anderson 1924: 153). Samuti on toonase kõige põhjalikuma saksakeelse maailmakirjelduse Sebastian Münsteri “Cosmographia” 1550. aastal ilmunud kordustrükis kirjas, et paljud liivimaalased on kohtu ees tunnistanud, et nad suudavad end huntideks muuta $^{3}$ (Metsvahi 2015a: 206). "Cosmographia” esimeses trükis, mis avaldati aastal 1544 ja mis oli kõige esimene saksa haritlase maailmakirjeldus, ei maini Münster libahunte kordagi, ent aastatel 1547-1548 oli külastanud Liivimaad Hesseni teadlane ning Münsteri kirjeldus põhineb tema vahendatud informatsioonil. Seega lähtusid lood inimese hundiks muutumise võimest Liivimaalt, mitte Saksamaalt.

Ka 1560. aastal kirjapandud ning esmapilgul välismaalt pärinevana näiva teate algkodu on lähemal vaatlusel Liivimaa. Nimelt kirjutas Philip Melanchtoni väimees Caspar Peucer juhtumist Liivimaal, mis tõendab, et inimesed suudavad ennast hundiks muuta:

On üks tõestisündinud lugu teatud talupojast libahundist, kes õhtustas oma linnafoogtiga Riia linna lähedal. Purju jäänuna jäi ta lõpuks magama ja kukkus kõrgemast seisusest isikute juuresolekul pingilt põrandale. Foogt oli tark mees, kes sai kohe aru, et see mees on libahunt. Ta palus oma teenritel ära minna ja pani siis talumehe voodisse. Järgmisel päeval leiti karjamaalt hobune, kes oli keskelt lõhki lõigatud. Foogt sü̈̈distas 
meest, kes oli eelmisel õhtul kokku kukkunud ja sel hommikul üles tõusnud. Ta vangistati ja üle kuulatuna tunnistas kohe oma süüd. Ta väitis, et oli ühte liblika kujul ringi lennanud nõida taga ajanud (libahundid nimelt uhkeldavad sellega, et nende töö on nõidu tõrjuda), et ohu eest kaitsta. Juhuse tahtel oli nõid peitnud end hobuse alla. Libahunt hiilis lähemale, sirp käes, ja lõi siis jõuliselt, aga kavatsetust napilt mööda, ning tulemuseks oli see ootamatu sündmuste käik, ta lõikas kogemata hobuse kaheks. Sellised on deemonite omavahelised mängud, mida nad mängivad hoolimata suurest kahjust, mis inimsoole selle läbi osaks saab. (Minu tõlge ingliskeelsest tõlkest Ginzburg \& Lincoln 2020: 201-202, mis on tõlgitud ladina keelest ${ }^{4}$, ladinakeelset originaali vt Ginzburg \& Lincoln 2020: 202 või Bruiningk 1924: 180.)

Raamat, millest see lõik pärineb, oli pealkirjastatud "Commentarius de praecipuis generibus divinationum” ning see ilmus Wittenbergis. Peucer oli kõrgeltharitud mees, kelle sõnades polnud põhjust kahelda, seda enam, et ta ise libahundi teema sissejuhatuseks kirjutas, et kui ta varem pidas inimese võimet muutuda hundiks väljamõeldud naeruväärsuseks, siis pärast Liivimaalt kuuldut on ta oma seisukohta muutnud. Lisaks konkreetsest hundistumisvõimega mehest pajatavale loole jagas Peucer ka üldisemat informatsiooni Liivimaa libahuntide kohta. Ta teatas, et on usaldusväärsest allikast kuulnud, mis toimub Liivimaal ja selle naaberaladel igal aastal kaksteist päeva pärast jõule. Nimelt koguneb siis kokku mitu tuhat libahunti ning nende eesotsas on lonkava jalaga poiss. Libahundid ründavad kõiki kariloomi, kes nende teele satuvad, ja rebivad nad hammastega lõhki. (Bruiningk 1924: 176; Ginzburg \& Lincoln 2020: 197-198.)

Sama lugu, mille edastas Peucer, on kirja pandud ka Augustin Lercheimeri raamatus "Christlich bedencken und erinnerung von zauberey" (1597), milles on juttu ühest teisest vangistatud talupojast, kes suutis ennast hundiks muuta, aga ka näiteks üle jõe lennata (Bruiningk 1924: 179). Lercheimeri pseudonüümi taga peitis ennast Melanchtoni endine õpilane ja Riia ladinakooli rektor Hermann Wilken (Witekind), kes oli kirjavahetuses Melanchtonile Liivimaa libahuntide kohta teavet edastanud. Seega oli too "usaldusväärne isik", kes Caspar Peucerile Liivimaa libahuntidese kohta teavet jagas, mitte mõni liivimaalane, vaid hoopis Matrin Lutheri sõber Melanchton (Bruiningk 1924: 177-179). Selles teates leiab kinnitust, et juba 16. sajandi keskpaiku kutsuti libahunte kohtu ette, sest Wilkeni versioon eespool esitatud libahundiloost lõpeb järgmiselt:

See mees tunnistas, et ta ei ole midagi teinud, vaid pigem nägi seda unes... See noormees magas kogu öö kambris, ihu ja hingega; sellepärast ei saanud ta käia väljas nurmel, kus need sündmused aset leidsid. Kurat 
tegi seda ja sundis ta nii jõuliselt uinuma ja unenäkku, et ta uskus ja tunnistas selle enda tööks. Selle eest põletati ta. (Minu tõlge inglise keelest, Ginzburg \& Lincoln 2020: 202.)

1555. aastal kirjutas Liivimaal väga levinud usust libahuntidesse Olaus Magnus oma teoses "Historia de gentibus septentrionalibus". Ta käsitleb teemat üsna põhjalikult, tuues ära ka mitu tõestisündinud lugu hundistumisvõimelistest talupoegadest. Üks Olaus Magnuse vahendatud lugu kõneleb aadlimehest, kes on pikal reisil suurt metsa läbides sunnitud peavarju puudusel koos saatjaskonnaga metsas ööbima. Kuna kõigil on kõhud tühjad, pakub kaasas olev talupoeg välja, et võib hankida seltskonnale liha, palub kõigil vait olla, kui nad peaks vahepeal midagi erakordset nägema, muudab ennast siis hundiks ja toobki söögiks lamba (Olaus Magnus 1845: 102-103).

Kuna põhjapoolsete rahvaste elu kirjeldusi oli tollal ülivähe, sai Olaus Magnuse teos väga tuntuks. Tema eeskujul ei jätnud peaaegu ükski varase uusaja Baltikumi kirjeldaja mainimata siinsete kohalike elanike hundistumisvõimet (Donecker 2010). Saksa ajaloolane Stefan Donecker on näinud seda sotsiopoliitilise võttena, mis aitas Euroopas kujundada ettekujutust siinsetest põliselanikest. On teada, et paljud siinsetest elanikest ei olnud kristlust oma südames omaks võtnud ning järgisid rahvapärast usundit, mis põimis katoliiklikke ja eelkristlikke elemente. (Lust \& Küng et al. 2011: 179-181) Hundiks muundumise võime omistamine sellistele barbaarsetele ja metsikutele inimestele Euroopa vähetuntud perifeerias osutas nende "paganlikkusele", andes märku, et neid on vaja tsiviliseerida ${ }^{5}$ ja ristiusu tõdede juurde juhatada. Samas muutis loomtransformatsiooni võime põliselanikud kardetavaks ning andis välismaailmale märku, et nad võivad oma üleloomulike võimetega ametlikku võimu ohustada (vt Donecker 2012: 313).

Käesoleva artikli seisukohalt pole oluline siiski mitte libahundi kujutelma seostamine põliselanikega kui sotsiopoliitiline samm välismaailma tarvis, vaid see, kas ja kuidas kohalikud elanikud uskusid inimese võimesse hundiks muutuda ning kuidas see kujutelm teisenes sajandite vältel.

\section{Nõiaprotsessid libahundi kujutelma maaletoojana}

Eestimaalt ja Liivimaa sellest osast, mis jääb praeguse Eesti territooriumile, on säilinud umbes 150 nõiakohtuprotokolli. Valdav osa neist pärineb 17. sajandist ning ainult üksikud 16. sajandist (Madar 1987: 126). Neist 18 protsessil süüdistati külainimeste seast pärit naisi (18 naist) ja mehi (13 meest) libahundina 
kahjustamises (Madar 1987: 138). Muu Euroopa nõiakohtuprotsesside andmetega võrreldes on see suhtarv üsna suur (Metsvahi 2000: 17).

Inimese võime hundiks muutuda, et loomi ja inimesi rünnata, hakkas kuuluma nõiaprotsesside süüdistuste hulka Šveitsis, Prantsusmaal, Madalmaades ja Püha Rooma riigi teatud piirkondades alates 15. sajandist (Plukovski 2015: 83). Liivi- ja Eestimaa kohtutesse jõudis libahundiusk ilmselt 16. sajandil ning siinsete süüaluste tunnistuste järgi puudutas see loomade, mitte inimeste ründamist (Metsvahi 2015a: 219). Vaatamata sellele, et kohtualune võib piinamise tagajärjel omaks võtta identiteedi, mis läheb vastuollu tema tavapärase identiteediga (Henningsen 1980: 21), on vähetõenäoline, et ta tunnistaks midagi sellist, millele tema kultuuriruumis mingisugust tähendust ei omistatud. Seega võib kindlalt väita, et libahundiusk baseerus rahvapärasel loomtransformatsiooni kujutelmal, mis põimus demonoloogilise õpetusega. Uskumuse rahvapärast päritolu kinnitab asjaolu, et libahundiusk säilis ka sel ajajärgul, mil kohtutes 1686. aasta lõpust alates piinamismeetodit enam ei kasutatud (vt Metsvahi 2001c: 101).

Rahvapärases maailmamõistmises oli inimese ja looma suhte iseloom üsnagi teistsugune kui kristliku mõtte omaks võtnud kõrgkihtide seas. Kui mõjukas antiikaja filosoof Aristoteles oli inimest käsitanud veel osana loodusest, siis kristlikus maailmanägemises eraldus inimene loodusest, tõustes sellest väljapoole ning ühtaegu selle üle. Sarnaselt inimesele seisab ka maailma looja Jumal loodusest lahus ning looduse ilugi hinnatakse mitte loodusest endast lähtuvalt, vaid Jumala kaudu (Descola 2014: 66).

Kahte täiesti eraldi kategooriat "loodus" ja "inimkond" hakati Euroopas eristama alles alates 17. sajandist (Descola 2014: 69) ning eesti talurahva seas sellest tõenäoliselt veel mitu sajandit hiljem. Ent isegi selle dualistliku eristuse eeletapp - arusaam Looja ja looduse eraldatusest ja inimese eeldatavast positsioonist loodusest väljaspool - polnud 16.-17. sajandiks veel talurahva sekka jõudnud.

Ka demonoloogide ja haritlaste seas ei olnud loomtransformatsiooni küsimuses selgust. Nõiausu käsiraamatu "Malleus Maleficarum" (1487) loomtransformatsioonile pühendatud peatükist selgub, et nii talurahva pärimusest kui ka antiikaja lugudest demonoloogidele tuttavad lood inimese muutumisest loomaks osutusid probleemseks (Spencer \& Institoris 1923: 63). Filosoof Jean Bodin peab oma 1580. aastal Pariisis ilmunud raamatus "Deonomanie des sorciers" moondumislugusid tõeks (Bodin 1591: 118-129; vt ka Vähi 2006: 105-107). Arst Johann Wier näiteks püüdis aga juba 1564. aastal oma raamatus "De praestigiis daemonum" taandada kuradinägemused ajupingetega ja meeleoluga seotud häiretele (Schenda 1961: 46-47). Enamjaolt väidetigi, et tõelist muutumist 
toimuda ei saa, sest see oleks Jumala ampluaa, libahundi puhul on tegemist kuradi põhjustatud silmapettega (Lercheim 1585: 26-27).

Arvatavasti olid 16. ja 17. sajandil üsna paljud nende seast, keda süüdistati libahundiks käimises, nõidadeks ${ }^{6}$ või maagideks peetud isikud. Nimelt on nõiaprotsesside uurijad kindlaks teinud, et Eesti- ja Liivimaa nõiaprotsessidel sattus nõiasüüdistusega kohtusse üsna palju professionaalseid maage: ravitsejaid, lausujaid ja õnnistajaid (Madar 1987: 135). Ka kõige kuulsam Liivimaal tegutsenud libahunt Thiess, kes väitis end olevat kogukonna hüvanguks tegutseva hea libahundi (vt Ginzburg \& Lincoln 2020; Blecourt 2007; Metsvahi 2000; Metsvahi 2021b), oli ravitseja ja vilja õnnistaja.

Nõiaprotsessidega külvati rahva sekka hirmu nõidade ja libahuntide ees, kes tulevat hävitada, kuna nad tegevat koostööd saatanaga. Üks osa talurahvast läks paanikaga kaasa ning üritas kasutada nõiakohut külasiseste konfliktide lahendamiseks. Ometigi annavad Thiesi ja mitmete teiste süüaluste kohtu ees antud tunnistused alust arvata, et eksisteeris ka vastukultuur, mille raames olid nõiad inimeste abistajad ning libahundid tavainimesest võimekamad ja avarama maailmatunnetusega isikud. Vastukultuuri mõiste kaudu on võimalik aru saada, miks kohtualune Alit (vt alapeatükist "Loomtransformatsioon 16. ja 17. sajandi ning 19. ja 20 sajandi libahundipärimuses"), surm silme ees terendamas, naeris kohtunikele näkku ning kohtualune Thiess väitis, et kirikuõpetaja on liiga noor mõistmaks, kuidas asjad maailmas tegelikult käivad.

\section{Ontoloogia, millele libahundiusk toetub}

Nagu eespool juba osutatud, viiks tänapäevasest maailmanägemisest lähtumine 16. ja 17. sajandi libahundikujutelma analüüsil ummikteele. Seega püüan siinkohal eeltoodust veidi põhjalikumalt analüüsida erinevusi toonase ja tänapäeva inimese maailma kategoriseerimise viisides, alustades eelmodernse talurahva maailmanägemisviisi põhialuste selgitamisest.

Kosmoses paiknevate entiteetide - nagu inimesed, loomad ja taimed - omadused ei sõltu seesuguse vaateviisi järgi mitte nende eeldatavast olemusest, vaid pigem kohast, mille nad hõlmavad omavahelistes suhetes (Descola 2014: 10). Nende entiteetide identiteet ega vorm ei ole ette paika pandud, vaid need on paindlikud ja sõltuvad tingimustest (Descola 2014: 23) - see erineb täiesti meie maailmanägemisest, milles identiteete ja vorme peetakse püsivateks. Sel moel lähenedes ei ole organism mitte elus asi, vaid kindla elus olemise viisi materiaalne kehastus (Ingold 2000: 89). Maailm ei ole aga mitte representatsioon, vaid pigem keha laiendus (vt Descola 2014: 283). Kuna elada tähendab olla asetatud suhetesse, mis kutsuvad esile mitmesuguseid vorme, seisab teadvus 
näiteks Põhja-Ameerika krii-indiaanlaste jaoks elu esirinnas, olemata midagi sellist, mille peaks lisama orgaanilisele elule. Krii mõiste "elu" sõnasõnaline tõlge on 'pidev sünd' (Ingold 2000: 51). Et inimenegi sünnib, kasvab ja sureb, sööb, kaitseb ennast ja sigib samamoodi nagu loomad, ei erine inimese ja looma koht maailmas põhimõtteliselt. Nii loom kui ka inimene on lihtsalt ühed võimalikud paigad, milles ilmneb avar omavaheliste suhete väli (Ingold 1994: 2).

Kui analüüsida, kuidas on inimesed ajaloo jooksul oma institutsioone mõistnud ja mõtestanud, selgub, et väga harva on eristatud sotsiaalset sfääri kui midagi kõigest muust eristuvat ja ainuüksi inimtegevusega seostuvat (Descola 2014: 247; näiteid abielu ja kosjade mõistmisest vt nt Metsvahi 2015b; Metsvahi 2021a). Väite võib keerata ka teisipidi: see, mida meie nimetame "looduseks", oli tihedalt lõimitud sotsiaalse elu sfääri (Descola 2014: 235). Alles üsna hiljuti - Eestis 19. sajandil ja kohati isegi veel 20. sajandi esimesel poolelgi - ei mõeldud, nagu tuleks inimesi ja mitteinimesi kohelda täiesti erinevatel alustel ${ }^{7}$ (vt Descola 2014: 248).

Keskkonnaga suhestuvad ühevõrra nii inimesed kui ka loomad (Ingold 1994: 14) ning tähendustavad seda igaüks vastavalt oma kogemusele. Valdavas osas inimkonna ajaloost on käinud keskkonnaga suhestumine selles tegutsemise kaudu (Ingold 2000: 42). Alles suhteliselt hilisel ajal on hakanud prevaleerima käsitus, et ülimuslik keskkonnale tähenduse andja on inimteadvus. See on paradoksaalses vastuolus teise tänapäeva teadusliku tõega, et inimene on evolutsiooniprotsessi tulemus, ahvist järgmine arenguaste (vt Ingold 2000: 108). See, et loomauurijatele on loomade teadvuse uurimine osutunud uurimisvaldkonnana väga kõvaks pähkliks, on pannud nad selle uurimisest loobuma ning kinnitama, et loomadel ei ole teadvust (Vilkka 2002: 288).

Et eri teadusvaldkondade esindajad tegutsevad üldiselt üksteisest distantseeritult, ei ole see loomade kohta käiv tõdemus pannud uurijaid lahti ütlema dualistlikust lähenemisest inimese puhul, mil kõneldakse Descartes'i vaimus endiselt kehast ja teadvusest eraldi, pidades keha justkui masinaks ning teadvust seda liigutavaks jõuks ${ }^{8}$ (vt ka Descola 2014: 62).

\section{Hundi austamine}

Loodusliku keskkonna ja sotsiaalse elu loomulikust lõimingust ning inimese ja looma paratamatust kokkukuuluvusest kõneleb ka eesti talurahva seas suhteliselt hilise ajani püsinud hundi austamise komme, mis kinnitab eespool esitatud väidet distantseeritud suhtumisest kirikukristlusse. Kuna hunt on kristlikus maailmas üldiselt negatiivsete karakteristikutega loom (vt Plukovski 2015: 92), on hundi austamise tava säilimine väga tähelepanuväärne. 
Veel 18. ja 19. sajandil ei olnud eestlased nõus hunte tapma - olgugi et selle eest lubati neile rahalist tasu -, sest pidasid teda sedavõrd austusväärseks loomaks (Metsvahi 2015a: 216). Respektist hundi vastu kõneleb ka see, et ühegi teise metslooma kohta ei leidu eesti pärimuses nii palju rahvajutte kui hundi kohta ning et ühelgi teisel loomal ei ole eesti keeles nii palju peitenimetusi kui hundil (Kõiva 2019: 194; vt ka Hiiemäe 2019: 44). Usuti, et hunt peab saama (kariloomade seast) oma jao, et ta liiga palju kariloomi maha ei murraks (vt nt Loorits 2001: 141; Rootsi 2005: 433). Mõnikord jäeti koguni mõni noorloom metsa hundile, et ta oleks rahul ja karjast rohkem ei murraks (Loorits 2001: 140). Veel 1977. aastal rääkis lõunaeestlane Rudolf Sordla: "Kui mingi loom, näiteks lammas ära tappeti, siis pidi esimene kaelalüli ehk -jakk metsa hundi jaoks visatama. [---] Seda kutsuti hundi jagu ja ise seda ei söödud" (RKM II 328, 244 < Võnnu khk, R. Sordla 1977; Rootsi 2005: 433-434). Austavat suhtumist hundisse väljendas ka komme, et kui hunt inimesele vastu juhtus tulema, tuli teda austusväärselt kõnetada (Rootsi 2005: 434-435).

Kui hunt oli looma maha murdnud, ei süüdistatud hunti, vaid öeldi, et ta oli "mets rikkund" (Loorits 2001: 13). Soomes, kus on läbi aegade elanud rohkem karusid kui hunte ning ka folklooris on karu sagedasem tegelaskuju kui hunt, tähendas "mets murdis lamba", "mets võttis..." ja "mets rikkus..." hoopis looma mahamurdmist karu poolt (Nirvi 1944: 88; vt ka Rootsi 2005: 463). Kui Soomes ja Karjalas oli karu nimetamine tabu, siis Eestis oli seda hundi nimetamine. Usuti, et kui hunti nimepidi kutsuda, tuleb ta kohale: "Hundi nime ei tohi ikka nimetada, kui seda nimetad, siis tema ka tõeste tuleb ehk ka murrab. Seda võib veel enem öelda m e t s t u l e b ehk mets murdis jne" (E 26306 (4)); Nirvi 1944: 88).

Seega kasutati teatud kontekstides metsa ja hunti sünonüümsetena ning metsale ohvri toomine oli samatähenduslik hundile ohvri toomisega (Nirvi 1944: 88-89; vt ka Tarkka 1994: 59). Usuti, et hunt ei kahjustaks karja, kui inimesed metsale ega hundile halba ei teeks, ning mets oleks puhas ja püha, kui inimene oma suhet metsaga ära ei rikuks (Tarkka 1994: 60). Karjus pidi olema valvel, et enne hunti näha, kui hunt teda silmab, sest arvati, et kui hunt karjust esimesena näeb, võtab hunt talt hääle ära (Loorits 2001: 146, 229).

\section{Loomtransformatsioon 16. ja 17. sajandi ning 19. ja 20. sajandi libahundipärimuses}

Eelmodernsele eesti talupojale omase ontoloogia järgi on loomtransformatsioon seega midagi sootuks muud, kui me oma praeguse maailmanägemise põhjal eeldaksime. Kuna loodust ei mõistetud lahus muust olevast, ei eristanud 
toonane inimene sotsiaalseid ja looduslikke kategooriaid (vt Descola 2014: 2324). Animistlik loodus ja see, mis on loodusest ülem, olid asustatud sotsiaalsete kogukondadega, millega inimesed lõid kõikide poolt jagatud normidega kooskõlas olevaid suhteid. Inimesed ja loomad said vahetada perspektiive, tunnusjooni ja mõnikord koguni kehasid. Just sel moel olid nad võimelised üksteisest aru saama (Descola 2014: 249).

1651. aasta Idavere (Haljala kihelkond) nõiaprotsessil rääkis 18aastane eesti noormees Hans, et ta on kaks aastat libahundina ringi liikunud ja väiksemaid loomi murdnud. Kohtunike küsimusele, kas ta tundis ennast hundiks olemise ajal mõistuse poolest inimese või loomana, vastas Hans, et loomana (Madar 1987: 138). Ei ole vaja ülearu palju tähelepanu pöörata sellele, et küsiti just mõistuse kohta. Samalaadse vastuse andis Hans ka siis, kui kohtunikud hinge kohta küsisid:

Kohtunikud tundsid huvi, kas ka Hansu keha võttis libahundiks jooksmisest osa või ainult tema hing 9 . Noormees kinnitas, et ta oli ise hundinahka pugenud ning näitas tõestuseks libahundina saadud koerahammustuse jälge jalal (Madar 1987: 138).

Hans ei erista hinge, mõistust ja keha üksteisest sel moel, nagu teeks seda meie või nagu küsimuses on eeldatud. Tema vastus peegeldab seda, mismoodi mõisteti loomtransformatsiooni eelmodernsel ajal - nimelt vahetusid hundiks käies inimese kavatsused looma omade vastu. Samamoodi vastaksid achuarid või kriid, kes on animistliku maailmanägemisega: kui nad omistavad mõnele asjale hinge, tähendab see, et sellel asjal on tahe, samamoodi nagu inimestel ja loomadel (Descola 2014: 188). Samasugust loomaomast tunnetust postuleerivat maailmanägemist väljendab ka 1615. aasta Harjumaa Kiviloo nõiaprotsessi süüalune ja hiljem oma elu tuleriidal lõpetanud Alit, kui ta vastab küsimusele, kas ta teab, kellele kuulusid loomad, kelle ta koos kahe teise nõiaga maha murdis, naerdes vastuküsimusega, et kas siis hunt kunagi enne loomade murdmist küsima läheb, kellele need kuuluvad (Ein Hexenprocess 1840: 342). Intentsionaalsus ja kehalisus on sedalaadi maailmanägemise juures harva teineteisest lahutatud (Descola 2014: 207).

16. ja 17. sajandi ettekujutused libahundist eristuvadki 19. ja 20. sajandi omadest just seetõttu, et nende aluseks oli erinev ontoloogia. Et selle ontoloogia järgi käib keskkonnaga suhestumine nii inimese kui looma puhul selles tegutsemise kaudu, tähendab loomaks olemine ühemõtteliselt loomana tegutsemist. Teiseks ei ole selle ontoloogia järgi ei inimesel ega loomal teineteisest eristuvat olemust, liiatigi ei ole neil kummalgi üldse püsivat olemust.

Niisiis on inimese loomaks muutumine varasema perioodi pärimuses loomulik nähtus, mis laiendab inimese võimalusi keskkonnaga suhestuda - ning 
sugugi mitte ainult demonoloogide poolt pealesurutud mõtteviisi kohaselt teistele entiteetidele kahju tehes, vaid ka rahvapärase mõtteviisi järgi kogukonna, kaaslaste või iseenda ellu uusi hüvesid luues. Meenutan, et vanemasse kihistusse kuuluvad kogukonnale head teha püüdes ja nõida taga ajades kogemata kombel hobuse tapnud Liivimaa talumees, talumees, kes hundi kujul aadlikulegi liha söögiks toob, ning Eestimaa naislibahunt, kes julgeb võimu esindavatele kohtunikele näkku naerdes kinnitada, et hunt teeb hundi tegusid ilma inimese kombel mõtlemata, kellele mahamurtavad loomad kuuluvad.

Libahundipärimuse uuemat kihistust esindava Armi talu sulase Matsi kohta käiva loo (vt alapeatükist “19. ja 20. sajandi libahundipärimus”) taustal olev maailmamõistmine on sootuks erinev. Uudishimulikule Matsile jäi hundinahk selga ning ta oli sunnitud muutuma hundiks vastu tahtmist. Hundina aga takistas teda ta algupärane inimolemus ning ta ei suutnud oma hundinälja kustutamiseks piisavalt palju loomi murda. Kui ta sai õnneliku juhuse läbi taas inimeseks, ei taastunud kõik ta inimlikud jooned, tema hääl ja välimus jäid alatiseks meenutama pealesunnitud hundiks olemise perioodi. Matsi transformatsioon oli modernsema rahvapärase ontoloogia seisukohast ebaloomulik.

\section{Lõpetuseks}

Moraalsuse omistamine ainuüksi inimesele, mis on tihedalt seotud kartesiaanliku dualismi ja kristlusega, kujutab endast inimkonna ajaloos suhteliselt hilist algupära nähtust. Animistliku ontoloogia järgi, mis oli omane Eesti- ja Liivimaa talurahvale nõiaprotsesside algusajal, polnud universaalseid loodusseadusi nii nagu need eksisteerivad meie maailmanägemises. Oleva füüsilisest mitmekesisusest tähtsam oli moraalse subjekti universaalsus, mis autoriseeris inimeste ja mitteinimeste suhted (Descola 2014: 199).

Nagu selgus, muutus artiklis vaadeldud kahe perioodi vahel uskumuste taustaks olev rahvapärane ontoloogia, mille tõttu ei suhtutud üleminekusse inimesest loomaks ja vastupidi enam nii endastmõistetavalt kui varem. Rahva sekka oli jõudnud 17. ja 18. sajandil ainuüksi õpetlaste seas levinud seisukoht, et inimesel on teadvus, aga loomal ei ole, ning loomaks olemine oli muutunud varasemast alaväärsemaks ja taunitavamaks.

Sellele taustsüsteemi kiirele vahetumisele oli kaasa aidanud ka demonoloogide edukus rahva seas nn üleloomulike võimetega isikute halbadeks nõidadeks tembeldamisel. ${ }^{10}$ Taustsüsteemi muutus tõi endaga kaasa ka animistliku keskkonnaga sümbioosis elamise tunde järk-järgulise vähenemise, nii et loodust austav suhtumine hüljati ja valdavaks sai üha negatiivsem hundi- ja metsastereotüüp. 
Nii nagu mets ja hunt, nii oli ka isik, kes oli võimeline hundiks muutuma, määratud loobuma paljudest oma positiivsetest tunnusjoontest. 19. ja 20. sajandi pärimusse oli jäänud küll veel jälgi võimekatest isikutest, kes olid suutelised oma kavatsuste ja tegutsemisareeni vahetamise nimel võtma looma kuju (vt nt Metsvahi 1999: 113-114, Metsvahi 2019: 145), aga üldiselt olid need isikud juba marginaliseeritud (vt nt Metsvahi 2019: 147-148).

Osa motiive, mida nõiaprotsesside ajajärgul oli seostatud libahuntidega, seostati (nõiaprotsesside ja muistendiüleskirjutuste) vahepealsel ning hilisemalgi ajajärgul hoopis inimtegelaskujudega, kes pole võimelised hundiks muutuma. 19.-20. sajandi allikatest on teada, et nõidadel (keda mõnikord kutsuti hambameesteks) oli võime hunte kariloomi murdma sundida või vastupidi hunte kinni hoides karja kaitsta, seega suutsid nad hunte valitseda ja käskida (Loorits 2001: 8, 170-172). Samuti kasutas osa külakarja valvavaid karjuseid hundisõnadeks kutsutud loitse, mille abil sai metsa "kinni panna", nii et hundid ei pääsenud enam metsast välja loomi murdma (Loorits 2001: 104).

Seega leidus veel 19. sajandi teisel poolelgi jäänukeid loodust austavast suhtumisest ning inimese ja looma vaheline kuristik polnud veel nii sügav ning arusaam keha ja hinge dualismist veel nii jäik nagu tänapäeval. Ometigi tuleb tunnistada, et sel ajal eristusid ühelt poolt inimene ja loom ning teiselt poolt mistahes organism ja tema elukeskkond siiski palju tugevamalt kui 16. ja 17. sajandil. Inimesel usuti olevat oma loomus või sisemaailm ning loomal oma. Seepärast ei võetud inimese loomaks muutumist enam loomulikuna ning inimese hundistumisega seostus palju võõrast ja negatiivset. Hundiks muutumise võime ei varustanud nüüd inimest maailma tajumise ühe lisavõimalusega ning uue kogemuste ja hüvede hankimise viisiga, vaid hoopis vaesestas tema inimolemust, mis usuti olevat looma omast nii mitmeski mõttes üle.

\section{Tänusõnad}

Artikli valmimist on toetanud Eesti Teadusagentuur (projekt PRG670).

\section{Kommentaarid}

1 Moderniseerumisega kaasnenud majanduslikud, sotsiaalsed ja mentaalsed muutused, mis toimusid erilise hooga just 19. sajandi keskpaiku, lähendasid Baltimaid muule Euroopale ja euroopalikule arengumudelile. Ea Janseni arvates "mõjutas moderniseerumine Baltikumi rahvastikku tema transiitasendi ja ajaloolis-sotsiaalse arengu läänelike traditsioonide tõttu enam kui mõndagi teist [Vene impeeriumis elavat rahvarühma]" (Jansen 2007: 185). 
${ }^{2}$ Meelelahutusmuistend on oma usundilise tähenduse kaotanud rahvajutt, mis on jäänud pärimusse püsima tänu elementidele, mida tõlgendatakse nüüd fantaasiarikaste ja põnevatena (vt ka Metsvahi 2000: 50).

3 See Münsteri tsitaat on läinud eestikeelsesse käibesse kahjuks vale tõlkena, milles kohtu ees tunnistamist ei mainitagi: "Sel maal [---] on niisugune ebausk, nagu seda siin minevikus tihti tunti, et nad võivad huntideks moonduda, joosta ja kahjustada kõike, kuhu nad tulevad, ja seejärel muudavad nad end jälle inimesteks, ja niisuguseid hüütakse libahuntideks" (Laidre 2015: 19; täpselt sama tõlge - kui üks asesõna "nad" välja arvata - leidub ka Laugaste 1963: 26 ja Vähi 2010: 244-245). Õige tõlge on: "[...] on niisugune ebausk, nagu nad on kohtus sageli tunnistanud, et nad võivad huntideks moonduda [...]" (vt saksakeelset originaali Laugaste 1963: 24 ja tõlget inglise keelde Donecker 2012: 295).

4 Tänan Kaarel Veskist, kes tõlget parandas. Täpsustusi tegin lisaks ka saksakeelse refereeringu järgi (vt Bruiningk 1924: 178-179).

5 Hunti ja metsa kasutasid võimud barbaarsuse võrdkujudena ka 18. sajandil. 1764. aastal kirjutas Vene impeeriumi valitseja Katariina II, kes lähtus Vene riigi kui terviku huvidest ega olnud huvitatud Balti provintside ulatuslikust autonoomiast, uuele kindralprokurörile: "[---] Nimetatud provintse [---] tuleb mõjustada muutuma venelikumaks ja et nad ei vahiks enam nagu hundid metsa poole" (Laur 2000: 208).

${ }^{6}$ Eesti sõna "nõid" ei ole tänapäeva tavakeeleski jäägitult negatiivse tähendusega, nagu ta on seda paljudes teistes Euroopa keeltes. Nõia mõiste sisaldab endas ka targa ja ravitseja konnotatsioone ja etümoloogiliselt ongi sel sõnal olnud positiivne tähendusväli.

7 1885. aastal pöördus eesti talumees Jaan Keerus Sürgavere kogukonnakohtu poole, et süüdistada Tõnis Viilupit tema toakoera jala vigastamises, nõudes hüvitiseks suure summa raha (sada rubla) ja väites, et tema koer "targem olnud kui inimene" (EAA.3541.1.13, 166/190, 114). Keeruline öelda, kas selles näites on tegemist vanapärase maailmamõistmise jäänukiga või uusaegse lemmikloomakultuse algetapiga. Minu arvamus kaldub esimese variandi kasuks.

8 Selline tõlgendus on viinud negatiivsete tagajärgedeni (ülearu tehnitsistlik maailmapilt, geneetiliselt muundatud organismid, mitmesugused keskkonnaprobleemid, kaasa arvatud tugevate elektromagnetväljade tungimine kõikjale), mille kumuleerumist katastroofiks püütakse leevendada sellesama ontoloogia raames, kuigi ainuõige lahendus oleks sellest loobumine ning tagasipöördumine ontoloogia juurde, mis taastaks otsekontakti keskkonnaga, pannes inimteadvuse naasma kõrgelt organismide elu vaatleja ja kontrollija positsioonilt ta päris rolli (Ingoldi (2000: 19) sõnu kasutades) "eluprotsessi enda esirinnas".

9 Väärib tähelepanu, et kohtunikud kasutavad oma küsimuses juba 17. sajandi keskel keha ja hinge vastandust. See näitab, et Eesti- ja Liivimaa vaimulikud käisid ühte jalga muu Euroopa toonaste teaduslik-religioossete mõttesuundadega.

${ }^{10}$ Seejuures tuleb siiski möönda, et demonoloogide katsed nõidu marginaliseerida edenesid visalt ning veel 17. sajandi lõpuski hooples Liivimaa ravitseja ja libahunt Thiess kohtu ees sellega, et mõistab maailma toimimist kirikuõpetajast paremini: "ta mõistab seda paremini kui härra pastor, kes on veel noor" (sõnasõnaline tõlge kohtuprotokollist aastast 1691: “(...) er verstünde es beszer als der Hr. Pastor, der noch jung wehre (...)”, Bruiningk 1924: 215). 


\section{Käsikirjalised allikad}

Eesti Rahvaluule Arhiiv Eesti Kirjandusmuuseumis:

E - Eiseni kogu

RKM - Eesti Riikliku Kirjandusmuuseumi kogu

Rahvusarhiiv:

EAA - Sürgavere vallakohtu ("kogukonnakohtu”) protokollid aastast 1885

Metsvahi, Merili 2000. Thiesi võitlused: 1692.a. Liivimaa libahundiprotsessil kõlanud tunnistuste usundiline taust: magistritöö. Tartu Ülikool, eesti ja võrdleva rahvaluule osakond.

\section{Kirjandus}

Anderson, Walter 1924. Uus töö Balti libahundiprotsesside kohta. Ajalooline Ajakiri 4, lk 151-154.

de Blécourt, Willem 2007. A Journey to Hell: Reconsidering the Livonian 'Werewolf'. Magic, Ritual and Witchcraft 2, lk 49-67 (doi: 10.1353/mrw.0.0002).

Bruiningk, Hermann von 1924. Der Werwolf in Livland und das letzte im Wendenschen Landgericht und Dörptschen Hofgericht i. J. 1692 deshalb stattgehabte Strafverfahren. Mitteilungen aus der livländischen Geschichte 22. Riga: Kymmel, lk 163-220.

Descola, Philippe 2014. Beyond Nature and Culture. Chicago \& London: the University of Chicago Press.

Donecker, Stephan 2010. The Lion, the Witch and the Walrus. Images of the Sorcerous North in the 16th and 17th centuries. Trans. Internet-Zeitschrift für Kulturwissenschaften 17 (https://www.inst.at/trans/17Nr/4-5/4-5_donecker.htm - 11. jaanuar 2021).

Donecker, Stephan 2012. The Werewolves of Livonia: Lycanthropy and Shape-Changing in Scholarly Texts, 1550-1720. Preternature: Critical and Historical Studies on the Preternatural 2, lk 289-322 (doi: 10.5325/preternature.1.2.0289).

Ginzburg, Carlo \& Lincoln, Bruce 2020. Old Thiess, a Livonian Werewolf. A Classic Case in Comparative Perspective. Chicago \& London: the University of Chicago Press.

Henningsen, Gustav 1980. The Witches Advocate. Basque Witchcraft and the Spanish Inquisition. Reno: University of Nevada Press.

Ein Hexenprocess 1840. Das Inland: Eine Wochenschrift für Liv-, Esth- und Curland's Geschichte, Geographie, Statistik und Litteratur 22, lk 341-344.

Hiiemäe, Mall 2019. Väike loomaraamat rahvapärimusest. Tartu: EKM Teaduskirjastus. Ingold, Tim (koost) 1994. What is an Animal? London: Routledge.

Ingold, Tim 2000. The Perception of the Environment. Essays on Livelihood, Dwelling \& Skill. London: Routledge. 
Jansen, Ea 2007. Eestlane muutuvas ajas: seisusühiskonnast kodanikuühiskonda. Tartu: Eesti Ajalooarhiiv.

Kõiva, Mare 2019. The Wolf: Human/Non-human Relations on the Basis of Etiologies and Verbal Communication. Folklore: Electronic Journal of Folklore 77, lk 181-198 (doi: 10.7592/FEJF2019.77.koiva).

Laidre, Margus 2015. Domus belli. Põhjamaade Saja-aastane sõda Liivimaal 1554-1661. Tallinn: Argo.

Laugaste, Eduard 1963. Eesti rahvaluuleteaduse ajalugu. Valitud tekste ja pilte. Tallinn: Eesti Riiklik Kirjastus.

Laur, Mati 2000. Eesti ala valitsemine 18. sajandil (1710-1783). Tartu: Eesti Ajalooarhiiv.

Lercheimer, Augustin von Steinfelden 1585. Christlich bedencken und erinnerung von Zauberen /Woher / was / und wie vielfältig sie sei/ wem sie schaden könne oder nicht: wie diesem laster zu wehren / und die/ so damit behafft/ zu bekehren/ oder auch zu straffen sein. Heidelberg.

Loorits, Oskar 2001. Endis-Eesti elu-olu IV. Lugemispalu karjakasvataja elust. Eesti Rahvaluule Arhiivi toimetused 18. Tartu: Eesti Kirjandusmuuseum.

Lust, Kersti \& Küng, Enn \& Tannberg, Tõnu \& Türna, Tõnis (koost) 2011. Ajalooarhiivi varasalvest. Dokumente Eesti ajaloost Rootsi ja Vene ajal (17.-20. sajandi algul). Tartu: Eesti Ajalooarhiiv.

Madar, Maia 1987. Nõiaprotsessid Eestis XVI sajandist XIX sajandini. Kivimäe, J[üri] (koost). Religiooni ja ateismi ajaloost Eestis. Artiklite kogumik III. Tallinn: Eesti Raamat, lk 124-145.

Metsvahi, Merili 1999. Muundumised libahundimuistendeis. Lohetapja. Pro Folkloristica VI. Tartu: Eesti Kirjandusmuuseum, lk 111-122 (http://www.folklore.ee/rl/pubte/ee/NT/ profo6/Metsvahi.htm - 12. jaanuar 2021).

Metsvahi, Merili 2000. Muistend kui tegelikkus. Maa-alused. Pro Folkloristica VII. Tartu: Eesti Kirjandusmuuseum, lk 44-59 (http://www.folklore.ee/era/nt/PF7/7Metsvahi. htm - 12. jaanuar 2021).

Metsvahi, Merili 2001a. Werwolfprozesse in Estland und Livland im 17. Jahrhundert. Zusammenstösse zwischen der Realität von Richtern und von Bauern. Beyer, Jürgen \& Hiiemäe, Reet. Folklore als Tatsachenbericht. Vorträge der Tagung: 20.-24. September 2000, Dorpat. Tartu: Sektion für Folkloristik des Estnischen Literaturmuseums, lk 175-184.

Metsvahi, Merili 2001b. Neiu hundiks. Libahundimuistendi "Teine puhkajatest murrab looma" analüüs. Ariadne Lõng. Nais- ja meesuuringute ajakiri 1/2, lk 39-51.

Metsvahi, Merili 2001c. Libahunt Thiesi võitlused. Klaasmäel. Pro Folkloristica VIII. Tartu: Eesti Kirjandusmuuseum, lk 101-113 (www.folklore.ee/era/nt/PF8 - 12. jaanuar 2021).

Metsvahi, Merili 2011. Die Frau als Werwölfin (AT 409) in der estnischen Volkstradition. de Blecourt, Willem \& Tuczay, Christa A. (koost). Tiervewandlungen. Codierungen und Diskurse. Tübingen: Francke Verlag, lk 193-219. 
Metsvahi, Merili 2015a. Estonian Werewolf History. de Blecourt, Willem (koost). Werewolf Histories. Palgrave Historical Studies in Witchcraft and Magic. Palgrave Macmillan, lk 206-227 (doi: 10.1007/978-1-137-52634-2_9).

Metsvahi, Merili 2015b. Venna ja õe abielu tagajärjel tekkinud järve muistend. Perekonnaajaloolisi tõlgendusi. Keel ja Kirjandus 8/9, lk 573-588.

Metsvahi, Merili 2019. "Ühel mehel käind naine undiks..." Saaremaalt kogutud libahundimuistenditest. Paar sammukest XXVII. Eesti Kirjandusmuuseumi aastaraamat 2010, lk 137-168 (doi: 10.7592/PS/27.metsvahi).

Metsvahi, Merili 2021a. Die Ehe und das Verständnis von Ehe in der bäuerlichen Estlands and Livlands in 18. Jahrhundert. Nordost-Archiv. Zeitschrift für Regionalgeschichte 28, lk 162-214.

Metsvahi, Merili 2021b. Libahunt Thiessi saladuse jälil. Carlo Ginzburg, Bruce Lincoln. Old Thiess, a Livonian Werewolf: A Classic Case in Comparative Perspective. ChicagoLondon: University of Chicago Press. Akadeemia 7, lk. 1304-1315.

Nirvi, Ruben Erik 1944. Sanankieltoja ja niihin liityviä kielenilmiöitä itämerensuomalaisissa kielissä: riista- ja kotieläintalous. Suomalaisen Kirjallisuuden Seuran toimituksia 223. Helsinki: Suomalaisen Kirjallisuuden Seura.

Olaus Magnus 1845. Des Olaus Magnus Bericht über die livländischen Werwölfe. Uebersetzt von Eduard Pabst. Über die Wuth der durch Zauberei in Wölfe verwandelten Menschen. Archiv für die Geschichte Liv-, Esth- und Curlands 4, lk 100-104.

Pluskowski, Aleksander 2015. Before the Werewolf Trials: Contextualising ShapeChangers and Animal Identities in Medieval North-Western Europe. de Blecourt, Willem (koost). Werewolf Histories. Palgrave Historical Studies in Witchcraft and Magic. Palgrave Macmillan, lk 82-118 (doi: 10.1007/978-1-137-52634-2_4).

Rootsi, Ilmar 2005. Tuli susi soovikusta. Tartu: Greif.

Schenda, Rudolf 1961. Die Französische Prodigienliteratur in der zweiten Häfte des 16. Jahrhunderts. München: Max Hueber Verlag.

Sprenger, Jacob \& Institoris, Henricus 1923. Der Hexenhammer. Malleus Maleficarum II, Berlin, Leipzig.

Tarkka, Lotte 1994. Metsolan merkki - metsän olento ja kuva vienalaisrunostossa. Laaksonen, Pekka \& Mettomäki, Sirkka-Liisa (toim). Metsä ja metsänviljaa. Kalevalaseuran vuosikirja 73. Helsinki: Suomalaisen Kirjallisuuden Seura, lk 56-102.

Virkka, Leena 2002. Susi ympäristöeetikon silmin. Ilomäki, Henni \& Lauhakangas, Outi (toim). Eläin ihmisen mielenmaisemassa. SKS:n toimituksia 885. Helsinki: Suomalaisen Kirjallisuuden Seura, lk 278-297.

Vähi, Tiina 2006. Libahundikujutelmade teoloogilis-demonoloogilised tõlgendused. Usuteaduslik Ajakiri 1, lk 93-122.

Vähi, Tiina 2010. Libahundiuskumused arhailise õiguse ja moraali kontekstis. Ajalooline Ajakiri 1/2, lk 101-154.

Vähi, Tiina 2011. Kirjalikud teated eesti libahundipärimuse kohta kuni 20. sajandi alguseni. Õpetatud Eesti Seltsi aastaraamat 2010. Tartu: Õpetatud Eesti Selts, lk 242-267. 


\title{
Summary
}

\section{Werewolf lore of Estonia and Livonia as reverberation of changes in folk ontology}

\author{
Merili Metsvahi \\ Assistant Professor \\ Department of Estonian and Comparative Folklore, Institute of Cultural Research, \\ University of Tartu \\ merili.metsvahi@ut.ee
}

Keywords: Estonia and Livonia, Estonian folktale, folk belief, folk ontology, neoanimism, werewolf, witch trials

The article gives a short overview of the Estonian werewolf tradition in the 16th and 17 th centuries and a glimpse into the 19th-20th-century werewolf beliefs. The image of werewolf of the earlier and later periods is compared. The differences between the images of these two periods are explained with the help of the approaches of Tim Ingold and Philipp Descola, which ground the changes in the worldview taking place together with the shift from the pre-modern society into modernity.

The mental world of the 16th-17th-century Estonian and Livonian peasant did not encompass the category of nature, and the borders between the human being and the animal on the one side and organism and environment on the other side were not so rigid as they are in today's people's comprehension of the world. The ability to change into a wolf was seen as an added possibility of acquiring new experiences and benefits. As the popular ontology had changed by the second half of the 19th century - the human mind was raised into the ultimate position and the animal was comprehended as being inferior - the transformation of a man into an animal, if it was seriously taken at all, seemed to be strange and unnatural.

Merili Metsvahi on Tartu Ülikooli eesti ja võrdleva rahvaluule osakonna kaasprofessor. Tema uurimisteemad hõlmavad eesti perekonnaajalugu ja naise positsiooni perekonnas 18. ja 19. sajandil, pulmakombestikku, eesti rahvausundit ja rahvajutte ning jutustamise uurimist.

Merili Metsvahi is Assistant Professor at the Deptartment of Estonian and Comparative Folklore, University of Tartu. Her research interests include Estonian family history and the position of woman in the family in the 18th-19th centuries, wedding customs, Estonian folk belief and folktales and narrating.

merili.metsvahi@ut.ee 